\title{
NORMAS PARA APRESENTAÇÃO DOS TRABALHOS
}

1. Observar o padrão da Revista da $\Lambda$ NPOLL n. 6/7 em caso de dúvida sobre as normas abaixo elencadas;

2. Os trabalhos (artigos, resenhas, depoimentos, etc.) deverão ser enviados em disquete (Windows 6.0 ou compatíveis) e em três vias impressas, sendo uma com identificação e duas não. $\mathrm{O}$ disquete deve trazer uma etiqueta indicando o(s) autor(es) do trabalho e o programa utilizado;

3. O trabalho deve ser apresentado na seguinte seqüência: título do trabalho; nome(s) do(s) autor(es); resumo; palavras-chave; texto com notas ao pé da página; abstract ou résumé; keywords ou mots-clés; bibliografia;

4. $\Lambda$ primeira página deve incluir o título, centralizado, em maiúsculas, sem negrito ou grifo; o(s) nome(s) do(s) autor(es), em itálico, letras maiúsculas somente para as iniciais, duas linhas abaixo do título à direita, com um asterisco que remeterá ao pé da página para identificação da instituição a que o autor pertence; resumo (colocar a palavra RESUMO em caixa alta, itálico, três linhas abaixo do nome do autor, seguida de dois pontos; o texto-resumo deverá ser feito em itálico, corpo 10); palavras-chave (colocar PALAVRAS-CHAVE em caixa alta, itálico, seguidas de dois pontos; as palavras-chave deverão estar em itálico, corpo 10);

5. Tipo de letra: Times New Roman ou similar, corpo 12;

6. Espaçamento: espaço simples entre linhas e parágrafos; espaço duplo entre partes, tabelas, ilustrações, etc.; 
7. Adentramento 1 (um) para assinalar parágrafos;

8. Versos e trechos de textos blocados deven ser destacados como citação;

9. Tabelas, ilustrações (fotografias, desenhos, gráficos, etc.) e anexos devem vir prontos para serem impressos, dentro do padrão geral do texto e no espaço a eles destinados pelo(s) autor(es). Para anexos que constituem textos já publicados, incluir bibliografia completa bem como permissão dos editores para publicação;

10. Subtítulos: sem adentramento, em maiúsculas, numerados em número arábico; a numeração não inclui a introdução, a conclusão e a bibliografia;

11. ABSTRACT ou RÉSUMÉ: em caixa alta, itálico, três linhas abaixo do final do texto, seguida de dois pontos; o texto deverá ser feito em itálico, corpo 10); KEYWORDS ou MOTS-CLÉS, duas linhas abaixo do abstract ou resumé, em caixa alta, itálico, seguidas de dois pontos; as key words ou mots-clés deverão estar em itálico, corpo 10);

12. Referências no corpo do trabalho: entre parênteses, autor e data identificadora do trabalho, seguida de dois pontos e do(s) número(s) da(s) página(s) citada(s);

13. Notas: devem aparecer ao pé da página, corpo 10 , numeradas de acordo com a ordem de aparecimento; a chamada, o número referente à nota, deve estar sobrescrito; os destaques (livros, autores, artigos) devem ser dados em itálico e/ou negrito, conforme a necessidade;

14. Inexos: caso existam, devem ser colocados antes das referências bibliográficas, precedidos da palavra $\Lambda \mathrm{NEXO}$, sem adentramento e sem numeração; 
15. Referências bibliográficas: a palavra BIBLIOGRAFI em maiúsculas, sem adentramento, duas linhas antes da primeira entrada. Autores em ordem alfabética, sem numeração de entradas e com espaço entre as referências. $\Lambda$ s linhas da referência não são adentradas, nem mesmo a primeira. $O$ principal sobrenome de cada autor em maiúsculas, seguido de vírgula e das demais iniciais (do nome e sobrenomes). $\Lambda$ s iniciais de outros autores, quando houver, ou dos organizadores da obra de onde foi retirado o artigo, precedem o sobrenome. Título de livro, periódico ou capítulo em itálico. Na segunda entrada de um mesmo autor, seu nome é substituído por um traço. $\Lambda$ data identificadora da obra entre prênteses, após o nome do autor. Mais de uma obra no mesmo ano, distinguidas pelas letras a, b, c, etc., após a data.

OBSERVAÇূ̃O FINLL: $\Lambda$ desconsideração das normas implicará em não aceitação do trabalho. 


\section{HUMantas PLBuCAÇOES FFLCH/USP}

e-mail: editflch@edu.usp.br

Título Reusta daANPOLL 6/7

Coordenação Editorial $\mathrm{M}^{\mathrm{a}}$ Helena (.. Rodrigues

Revisão autores / Jandira Albuquerque de Queiroz

Diagramação Marcos Eriverton Vieira

Capa $\mathbf{M}^{\mathrm{a}}$ Helena (x. Rodrigues

Montagem Charles de Oliveira/Marcelo Domingues

Divulgação Humanitas Livraria - FFLCH/USP

Mancha $11,5 \times 19 \mathrm{~cm}$

Formato $16 \times 22 \mathrm{~cm}$

Tipologia BauerBorlni BT, Castle T e GoudyHandtooled BT

Papel off-set $75 \mathrm{~g} / \mathrm{m}^{2}$ (miolo) e cartão branco $180 \mathrm{~g} / \mathrm{m}^{2}$ (capa)

Impressão da capa Preto e Pantone $484 \mathrm{U}$

Impressão e acabamento Seção Gráfica - FFLCH/USP

Número de páginas 372

Tiragem 300 